\title{
Ethiological treatment of acute and chronic Chagas' heart disease
}

\author{
Instituto Dante Pazzanese de Cardiologia - São Paulo, Brazil
}

\begin{abstract}
The uncertaintties in the ethiological treatment of Chagas' Disease are consequence of the lack of entire knowledge of its pathogeny and the no existence of a healing criterium. There is a consensus that antiparasite drugs should be used in the acute phase of the infection, regardless of the infection route, in new crisis, in patients under immunossuppression and in organs transplantation. There is still controversy regarding subacute, chronic or indetermined phase or cases with mild cardiac/digestive forms, not included in the situations listed above neither in a research protocol.

The treatment includes oral benzonidazol $5 \mathrm{mg} / \mathrm{kg} / \mathrm{day}$, bid or tid for 60 days. In 71 patients monitored in this fashion, the authors have found $60 \%$ of negative xenodiagnostic at the end of treatment. It is still necessary, however, to continue to investigate and accomplishing more randomized trials to confirm the efficacy of such method, and also to try to obtain effective and less toxic agents. It is also fundamental to standardize a more reliable healing criterium.
\end{abstract}

UNITERMS: Chagas's disease. Benzonidazol. Cardiomyopathies.

$\mathrm{T}$ he controversy over parasiticidic drugs for Chagas' disease, especially in the chronic form, is grounded in the doubts about the pathogenesis and the real importance of the parasite. The documentation of parasitemia is difficult, and there is no way to test the real parasiticidic action of the drugs.
Address for correspondence:

Abilio Augusto Fragata Filho

Instituto Dante Pazzanese de Cardiologia

Av. Dr. Dante Pazzanese, 500

São Paulo - SP - Brasil - CEP 04012-001
Thet leubts about theeffebogenesissare grounded of the usual little significance ascribed to the acute phase and the bigger importance given to the chronic phase. Additionally, the parasite is rarely found in the peripheral blood or in the tissues during the chronic phase. Therefore, Margarino Torres' hypothesis (11) that defended the allergic mechanisms and the autoimmune mechanisms as the most important pathogenic factors for the chronic phase became stronger. Recent investigations showed the high antigenic potential of Trypanosoma cruzi and the importance of the existing reactions and changes (apud 5). This information is the most important issue in the validity of etiologic treatment of the chronic phase.

More recently, with the reactivation of the disease in patients with a heart transplant and immunossupression

Elias Boainain - ( $t)$ deceased 
therapy, the importance of the parasite assumes greater importance and so does the necessity of elimination of the parasite with parasiticidic drugs.

\section{HISTORICAL BACKGROUND}

Clinical and experimental etiological treatment was tried a long time ago in studies which were not scientifically controlled (apud 3). Packchanian tested 47 nitrofuranic compounds in infected mice, and only three drugs were effective at eliminating the parasitic blood forms: nitrofurazone, furaltadone and furasolidine. Nonetheless, the parasitic tissue forms were not eliminated by those drugs.

Employing the knowledge about the Trypanosoma cruzi biological cycle in the host, Brener (4) suggested in 1961 longer treatment trials in order to maintain a higher concentration of the drug in the peripheral blood to exterminate the parasite by "parasitic exhaustion". Brener (4) confirmed this information experimentally, documenting that the use of drug for 53 days was more effective than for 29 days.

Etiologic treatment of Chagas' disease was only made uniform when the "Study Group about Chagas' Disease" met in Rio de Janeiro in 1962. Since that meeting, several drugs have been tested in both chronic and acute phases of the disease employing the guidelines produced by the study group. Among eight drugs tested, only two were approved: nifurtimox and benzonidazole. Both drugs were tested with the same methods in many different clinical assays in the search of the highest efficacy with the lowest rate of side effects. The results gave credence to many other conclusions, but one in particular was that there was a "geographic difference" in parasiticidic action. Nifurtimox was effective in $80 \%$ of the patients (acute and chronic patients) in Chile, Argentina and Rio Grande do Sul. It was only $40 \%$ effective in chagasic patients from other locations within the Brazilian territory. This geographic difference was not recorded for benzonidazole, perhaps because there were several different strains of Trypanosoma cruzi.

In addition to nitrofurtimox and benzonidazole, new drugs have been tested such as ketoconazol, itraconazol and allopurinol-riboside. The outcome does not allow a definitive conclusion at this time. Our experience lead to the conclusion that itraconazol and allopurinol-riboside were ineffective, but our patient test sample was a small one $(6,7)$. Other authors believe that allopurinol-riboside may be a useful therapeutic alternative in selected cases of Chagas' disease (1).

Presently, the only drug available for the treatment is benzonidazole, a compound that has been used for both acute and chronic forms of the disease.

\section{THERAPEUTIC INDICATIONS AND PATIENT SELECTION}

\section{Acute phase:}

All patients in the acute should be treated phase regardless of the mode of infection. According to Malta (8), it is the unanimous opinion of several Brazilian specialists on this issue that treatment is indicated in this phase.

\section{Chronic phase:}

Etiologic treatment of this phase is more controversial, and several criteria are required to qualify the patients for treatment. Table 1 depicts the conclusions drawn by the "Study Group about Chagas' Disease" during the Second Meeting of Applied Research to Chagas' Disease held in Araxá (MG) in 1986. These recommendations acknowledged a treatment indication for the chronic forms of the disease, indeterminate and cardiac

\section{Table 1}

Etiologic treatment for Chagas' disease: indications

1. Acute phase with any transmission mechanism.

2. Reactivation in patients on immune depressant medication therapy.

3. Children or adults in the chronic phase with a recent infection.

4. Indeterminate and mild cardiac form in clinical research protocol

5. Chronic digestive form along with or not with mild cardiac form in a clinical investigation protocol. If megaesophagus is also present, this could not interfere with drug absorption.

6. Organ transplant. 
(without great damage), only in clinical investigations. We understand by cardiac form without great damage when the heart is normal sized or shows a mild enlargement of a chest film, when there are no severe arrhythmias, no advanced heart blocks, heart failure or syncope.

At the Instituto Dante Pazzanese de Cardiologia in São Paulo, we employ the criteria shown in table 1 to prescribe treatment. The exclusion criteria are shown on table 2.

We indicate this treatment in the indeterminate and mild cardiac/digestive forms independently of the research

\section{Table 2}

Exclusion criteria to etiologic treatment in the chronic phase

1. Severe cardiac disease.

2. Severe medical condition that compromises the patient's outlook.

3. Malnutrition

4. Older than 50 years.

5. Resident in a high-risk for reinfection area.

protocol because side effects are well tolerated and because there is a theoretical and potential benefit from the drug. We also explain to the patient the unknown efficacy of the treatment and the drug toxicity.

Based on the research protocol, we should demonstrate the presence of the parasite in the peripheral blood. However, these tests (xenodiagnosis and blood cultures) are expensive and carry several technical problems as low specificity (40\%). In this situation, we treat the patients even without parasite demonstration.

\section{THERAPEUTICS WITH BENZONIDAZOLE}

\section{Dosage:}

In either the acute or in the chronic phase, we use benzonidazole at $5 \mathrm{mg} / \mathrm{kg} /$ day two or three times a day for 60 days (each tablet carries $100 \mathrm{mg}$ of benzonidazole).

\section{Side effects and toxicity:}

They are: dermatitis, peripheral polineuropathy, appetite loss, leukopenia. A high prevalence of malignant lymphoma was observed in mice that received the drug in the peritoneum. Other studies did not confirm this complication (apud 10). Moya registered clastogenic effects with Nifurimox and Benzonidazole in three patients. This information lacks further confirmation.

The dermatitis was allergic in nature, and it could also be widespread. It occurs regardless the dosage and it manifests usually in the second week of treatment. The severity is variable and sometimes requires discontinuation

Table 3

Benzonidazole therapy - chronic phase

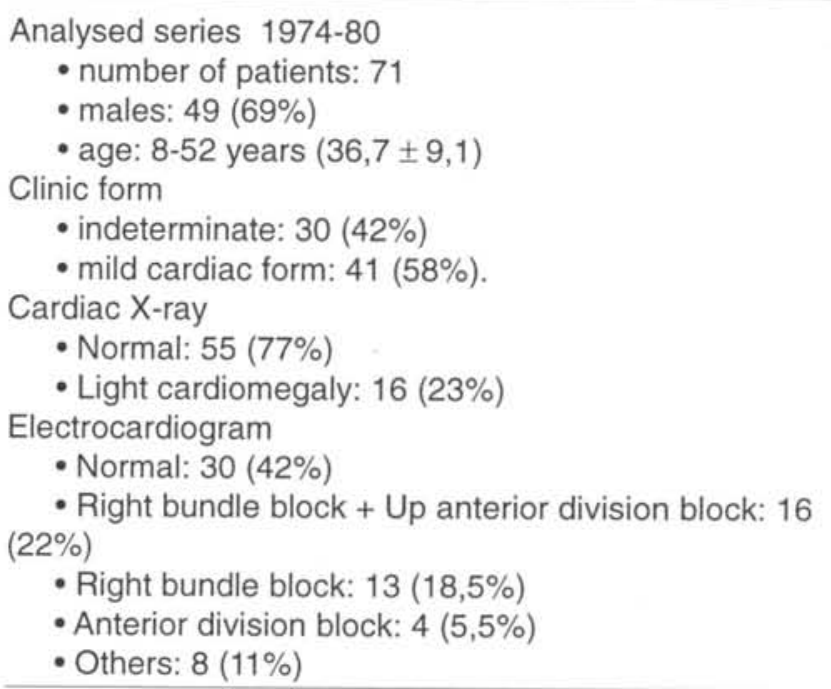

Benzonidazole therapy - Side effects in 71 patients

\begin{tabular}{lll} 
Diagnosis & patients & $\%$ \\
\hline dermatitis & 27 & $38 \%$ \\
polineuropathy & 26 & $36 \%$ \\
appetite loss & 12 & $17 \%$ \\
others & 5 & $7 \%$ \\
none & 21 & $30 \%$ \\
\hline
\end{tabular}


of the treatment. In our series of 71 treated patients (tables 3 and 4), 27 patients (38\%) developed dermatitis, which is usually treated with anti-histamine medication. No patient had to stop the treatment.

The peripheral polineuropathy mainly in the lower limbs is a more serious complication. It occurred in 26 patients $(36 \%)$. When severe, it could render the patient incapable of walking, and the symptoms can remain for several months after it is stopped. No patients in our series had to discontinue treatment because of the development of peripheral polineuropathy. Peripheral neuropathy symptoms may subside a little with B vitamins.

Appetite loss with occasional loss of weight occurred in $12(17 \%)$ patients. Drug treatment was discontinued only in the more severe cases.

Leukopenia and granulocytopenia are rare complications. A periodic white cell count (WBC) is mandatory each 15 or 20 days. This complication may occur between the second and the fourth weeks of treatment and the drug must be stopped (10). None of our patients developed this type of complication.

Other side effects of less importance include nausea, vomiting and insomnia.

\section{CURE CRITERIA}

There are no cure criteria accepted by all authors to certify that the treatment was effective.

We employ three criteria, namely: serological, parasitic and clinical.

In the acute phase, the serology always become negative, expressing a state of cure. In the chronic phase, it rarely becomes negative and when it happens, it is difficult to ascribe to the effects of the therapy. In our series of patients only 2 out of 71 patients $(3.8 \%)$ had negative tests.

The parasitic eriterion requires negative tests. In the chronic phase, the xenodiagnosis and blood cultures are employed to determine the presence of the parasite. However, these tests display low sensibility and reliability rates. Therefore, it is difficult to confirm the absence of the T. cruzi.

Blood cultures show in the chronic phase a positive yield of $45 \%$ after a 90 -day period for the results. Xenodiagnosis shows less than 40 diagnostic yield. It is made in three sessions with a two-week interval. We employ 40 third internship nymphs of $T$. infestans for testing. The results becomes available only after 30 and 60 days.
Finally, the clinical criterion demonstrates damage to different organs either by physical examination or by laboratory means such as a electrocardiogram or a chest film. It is the worst of all three criteria. In the acute phase, the clinical manifestations disappear in two to three months with or without treatment. In the chronic phase, the organ damage is irreversible.

\section{RESULTS}

There is no cure criterion beyond question. Therefore, it is difficult to assess the results. The recommendations of the discussion meeting about Chagas' disease published in 1963 are still used presently require the following: Both the blood tests and the parasitemia become negative after treatment.

Rassi (10) stated that the therapeutic efficacy with serological tests and xenodiagnosis could be evaluated in both acute and chronic cases with a recent infection. Both tests have two possibilities:

a) If, a long time after treatment, both tests are negative, we acknowledge the infection is cured. Negative blood tests are not immediate but it happen one or three years later or even longer.

b) If both tests become positive, the treatment failed. In this case, the xenodiagnosis becomes positive in six to 24 months.

Three situations could happen in the chronic phase:

a) After the treatment, both tests become positive, showing treatment failure.

b) Several negative xenodiagnostic tests with positive serological tests (dissociated cases). This is the most common situation. To some authors, this means treatment failure. To other authors, this is the equivalent of a serological scar (antibodies without the parasite) as seen with FTABS in syphilis infection and serological tests in Bouba.

c) The third situation concerns the patients who become negative in the xenodiagnosis after treatment. However, serological tests are doubtful (serological oscillation). This could persist permanently. In these cases, an "immunologic memory" could be the explanation.

In our unit, the parasitic criterion in employed to record cure. If we obtain 24 consecutive negative xenodiagnostic tests performed at a 30-day interval after treatment is terminated, we consider it a cure. According to this criterion, we have a $61 \%$ parasitic cure rate (table 3 ). These data are similar to other published series. 


\section{POST-TREATMENT FOLLOW-UP}

The aim of treatment in the chronic phase is to have a better clinical follow-up picture when compared to untreated patients. A comprehensive randomized investigation is necessary to confirm this hypothesis.

In the meantime, all that it is stated about treatment is hypothetical.

Our retrospective assessment employing electrocardiographic and radiological criteria show that within $7,19 \pm 5,36$ years of follow-up, 60 patients $(84 \%)$ became equal. That may be a sign of good prognosis. Before treatment, $42 \%$ of the patients were in the indeterminate form and $58 \%$ displayed a mild cardiac form of the disease. Five patients (7\%) deteriorated, and in three of them the xenodiagnosis became positive. One patient died in this period from causes unrelated to Chagas' disease.

\section{CONCLUSIONS}

The etiologic treatment of Chagas' disease demonstrates several doubtful points. Even in situations where treatment is a consensus (acute phase, reactivation with the use of immune depressant medication and before organ transplatation) there are no controlled and randomized studies confirming the scientific validity.
In the chronic phase, except in immune supression and organ transplantation, the doubts about treatment are based on the true action of the parasite as well as the immunological, and hypersensibility mechanisms that the T. cruzi elicit from the host. Common sense takes into account the parasite in the chronic phase and the possibility of antigenic stimulation. We admit that there are similarities with rheumatic disease when we know the real importance of the immunologic situation but we use penicillin to eliminate the Streptococcus.

Independent of the theoretical value of the etiologic hypothesis in the chronic phase, we should evaluate the efficacy of benzonidazole, the only drug available. Other studies and our experience show a great treatment failure when the parasitic criterion is employed. If we employ the serological criterion, a few patients could have a successful outcome.

Finally, we have to perform other studies to:

a) develop a new parasiticid drug with higher killing power on tissue and peripheral blood forms of the Trypanosoma cruzi;

b) develop a good cure criteria;

c) determine the validity of short- or long-term treatment.

In the meantime, if these responses are unavailable, the present evidence accounts for the use of benzonidazole in the acute phase of Chagas' disease as well as in some chronic forms. We need to be aware, and so do the patients, about the uncertainty of the results.

\section{Resumo}

As dúvidas acerca da terapêutica etiológica da doença de Chagas derivam de incertezas quanto à patogenia, associadas à inexistência de critério de cura satisfatório. Ainda assim, é consensual a indicação da terapêutica parasiticida na fase aguda da doença, independentemente da forma de transmissão, nas reagudizaçōes em pacientes sob imunossupressão, em crianças e nos procedimentos de transplantes de órgãos. É polêmica a indicação, excetuando-se os protocolos de investigação, nas formas crônicas indeterminadas, cardiaca leve e/ou digestiva, não enquadradas nas situaçōes acima.

O tratamento consiste no uso de benzodinazol por via oral $5 \mathrm{mg} / \mathrm{kg} / \mathrm{dia}$ em 2 ou 3 tomadas, por 60 dias.

Em 71 pacientes tratados com esse esquema, os autores obtiveram $61 \%$ de negativação do xenodiagnóstico. É necessário o prosseguimento das pesquisas e a realização de estudos multicêntricos randomizados para confirmar-se o beneficio da terapêutica, obter-se droga parasiticida mais eficaz e menos tóxica e estabelecer-se critério de cura confiável. 


\section{REFERENCES}

1. AGUILERA, X.; APT, W. \& ARRIBALDA, A. - Evaluación del alopurinol en le enfermedad de Chagas' cronica humana en Chile. Parasitol 11:32-4, 1987.

2. BELlotTi, G. \& PILEGGI, F. - Tryposonomiase e cardiopatia chagásica crônica. Arq Bras Cardiol 61:203-5, 1993.

3. BOAINAIN, E. - Tratamento etiológico nas doenças de Chagas na fase crônica. Tese apresentada à Faculdade de Medicina da Universidade de Goiás, 1977.

4. BRENER, Z. - Atividade terapêutica do 5-nitro-futaldeídosemi-carbozona (nitrofurazona) em esquemas de duração prolongada na infecção experimental do camundongo pelo Trypanosoma cruzi. Rev Inst Med Trop São Paulo 3:4-49, 1961.

5. BRENER, Z. - Immune response and immunepathology in $T$ cruzi infection. In: Wendel, S.; Brener, Z.; Camargo, M.E. \& Rassi, A. eds. Chagas' Disease (American
Tryposonomiasis): His impact on transfusion and clinical medicine. ISBT Brazil 92:31-47.

6. FRAGATTA F ${ }^{\circ}$, A.A.; BOAINAIN, E.; NAIFRINO, L.B.M. et al. - Itraconazol in treatment of Chronic Chagas' disease. Men Inst Oswaldo Cruz 88:243, 1993.

7. FRAGATTA $F^{\circ}$., A.A.; BOAINAIN, E.; PEREIRIA CHIOCCOLA, V.C. et al. - Allopurinol riboside in Chronic Chagas' Disease. Nom Inst Oswaldo Cruz 88:242, 1993.

8. MALTA, J. - Terapêutica da Doença de Chagas'. Consensos e Divergências. Arq Bras Cardiol 61:201-2, 1993.

9. PACKCHANIAN, A.O. - Chemotherapy of experimental Chagas' disease with nitrofuran compounds. Antibiotic and Chemother 7:12-23, 1957.

10. RASSI, A. \& LUQUETTI, A.O. - Therapy of Chagas' Disease. In: Wendel, S.; Brener, Z.; Camargo, M.E. \& Rassi, A. eds. Chagas' Disease (American Tryposonomiasis): His impact on transfusion and clinical medicine. ISBT Brazil 92:31-47.

11. TORRES, C.M. - Endocarditic parietale dans la maladie de Chagas. CR Soc Biol 99:886-7, 1928. 